\begin{tabular}{|c|c|c|}
\hline & Int.J.Curr.Microbiol.App.Sci (2017) 6(7): 2632-2636 & \\
\hline & $\begin{array}{l}\text { International Journal of Current Microbiology and Applied Sciences } \\
\text { ISSN: 2319-7706 Volume } 6 \text { Number } 7 \text { (2017) pp. 2632-2636 } \\
\text { Journal homepage: http://www.ijcmas.com }\end{array}$ & 30 \\
\hline $\begin{array}{l}\text { EXCELLENT } \\
\text { PUBLISHERS }\end{array}$ & & \\
\hline
\end{tabular}

Original Research Article

https://doi.org/10.20546/ijcmas.2017.607.371

\title{
Extent of Adoption of Hybrid Rice Seed Production Technologies by the Hybrid Rice Seed Growers
}

\author{
P. Sadvi ${ }^{1 *}$, M. Jagan Mohan Reddy ${ }^{2}$ and I. Sreenivasa Rao ${ }^{1}$ \\ ${ }^{1}$ Department of Agricultural Extension, College of Agriculture, \\ PJTSAU, Rajendranagar, Hyderabad, Telangana, India \\ ${ }^{2}$ KVK, Palem, Telangana, India \\ *Corresponding author
}

\section{A B S T R A C T}

Rice is the extensively grown food crop in India. Telangana is one of the states of the country suitable for hybrid rice seed production. Karimnagar is considered as one of the

\section{Keywords}

Hybrid rice seed production, adoption, Karimnagar, Telangana.

Article Info

Accepted: 29 June 2017 Available Online: 10 July 2017 potential district of Telangana state for Hybrid rice seed production. This hybrid rice seed production is taken up both by the public and private sectors in a big way. Hence, a study was taken up to find out the extent of adoption of hybrid rice seed production technologies by the respondents in Karimnagar district of Telangana state. The result of the study revealed that majority of the respondents had high extent of adoption followed by medium and low extent of adoption on hybrid rice seed production. Item analysis indicates majority of the respondents had adopted planting parental lines to come to flowering 21 days either prior or after the rice varieties grown nearby fields start flowering, practicing isolation distance of $100 \mathrm{mts}$ followed by transplanting the seedlings at the age of 20-25 days, rouging at tillering, flowering and at maturity stage, $\mathrm{A}$ and $\mathrm{R}$ lines are grown in 10:2 row ratio, application of GA3 before flowering stage, clipping of flag leaf for wide spread of pollen grains, Clipping of flag leaf for wide dispersal of pollen grains to get higher seed yield, following chemical weed control with Butachlor @ 2.5 1/ha, least ranked practices were nursery beds should be top dressed with nitrogen@600-800 g per $100 \mathrm{~m}^{2}$ of area, following seed treatment in paddy with Carbendazim and applying recommended quantity of FYM on last puddling.

\section{Introduction}

Rice (Oryzasativa) is perhaps the world's most important food crop being the staple food of over 50 percent of the world population, particularly of India, China and a number of other countries in Africa and Asia (FAO, 2006).Worldwide, rice is grown over an area of 161 m.ha with an annual production of about $764 \mathrm{mt}$. About 90.00 per cent of the world's rice is grown and produced in Asia. China is the main producer of rice, contributing more than 28.00 per cent of total global rice production (FAO, 2013). Rice (Oryza sativa L) is the most important staple food crop of India and is major source of calories for about 60.00 per cent of the world's population. In India, rice is grown in an area of 44.60 m.ha with a production of $109.50 \mathrm{mt}$ and average productivity of 2.62 tonnes per ha (Naresh et al., 2011). In order to keep pace with the growing population, the estimated rice requirement by 2025 is about $130 \mathrm{~m}$. t. Plateauing trend in the yield of 
HYVs, declining and degrading natural resources like land and water and acute shortage of labour make the task of increasing rice production quite challenging. The current situation necessitates looking for some innovative technologies to boost rice production. Hybrid rice is practically feasible and readily adoptable genetic option to increase the rice production. The rice hybrids, recently introduced in cultivation, on an average, give 10 to $15 \mathrm{q} / \mathrm{ha}$ additional yield over the conventional varieties (about $20 \%$ increase).

Therefore, the introduction of hybrids and popularization of their production technology are feasible and readily adoptable to achieve targeted production. The rigorous efforts of hybrid rice research and development in India since 1990s has resulted in release of 46 hybrids, 29 from public sector and 17 from private sector for commercial cultivation. During the year 2010, hybrid rice was planted in an area of $1.3 \mathrm{~m}$.ha and additional rice production of 1.5 to $2.5 \mathrm{mt}$ was added to Indian food basket through this technology (Hari Prasad et al., 2011). The present study was designed to draw the relationship between the independent variables and the extent of adoption of hybrid rice seed production technologies.

\section{Materials and Methods}

The study was conducted in Karimnagar district purposively with a sample of 120 hybrid rice seed growers. Ex-post factor research design was followed. 10 respondents were selected randomly from twelve villages of our mandals of the district.

Adoption is operationally defined as the extent of practicing / application of recommended cultivation practices of selected crop by the respondents. For this purpose a schedule was developed to test the extent of adoption of all recommended practices in hybrid rice seed production in consultation with the experts in Hybrid rice of various organisations and refined for validity and reliability. All the recommended cultivation practices which were included in the schedule were administered to respondents and their responses in the form of full adoption, partial adoption and non-adoption were obtained and the weightages of 3,2 and 1 were assigned respectively. The scores summated for all the items formed the total score of the respondent. The variable was measured with the help of schedule developed for the study consisting of fifteen statements and respondents were asked the feeling about these statements by indicating their level of adoption in terms.

\section{Results and Discussion}

Table 1 unveils that majority of the respondents had high extent of adoption $(55.00 \%)$ followed by medium $(26.66 \%)$ and low (18.33\%) extent of adoption of hybrid rice seed production technologies.

Table 2 indicates the item analysis of extent of adoption of hybrid rice seed production practices by the respondents. The ranks assigned to each item on extent of adoption indicates that majority of the respondents had adopted planting parental lines to come to flowering 21 days either prior or after the rice varieties grown nearby fields start flowering (I rank), practicing isolation distance of 100 mts (I rank) followed by transplanting the seedlings at the age of 20-25 days (II rank), rouging at tillering, flowering and at maturity stage (III rank), $\mathrm{A}$ and $\mathrm{R}$ lines are grown in 10:2 row ratio (III), application of GA3 before flowering stage (IV rank), clipping of flag leaf for wide spread of pollen grains (IV rank), Clipping of flag leaf for wide dispersal of pollen grains to get higher seed yield (IV), following chemical weed control with 
Butachlor @ 2.5 1/ha (V), staggered sowing for synchronisation in flowering (VI), Spray of $2 \%$ urea delays and phosphoric fertilisers enhances the flowering by $2-3$ days (VI), recommended seed rate of $12 \mathrm{~kg} / \mathrm{ac}$ and 6 $\mathrm{kg} / \mathrm{ac}$ for female and male respectively (VII), following rope pulling during anthesis for supplementing the pollination(VIII), least ranked practices were nursery beds should be top dressed with nitrogen @ 600-800 g per $100 \mathrm{~m}^{2}$ of area (IX rank), following seed treatment in paddy with Carbendazim (X) and applying recommended quantity of FYM on last puddling (XI).

Table.1 Distribution of respondents according their extent of adoption of hybrid rice seed production technologies

\begin{tabular}{|l|l|l|l|l|}
\hline S.No. & Category & Class interval & Frequency & Percentage \\
\hline 1. & Low extent of adoption & $17-26$ & 22 & $18.33 \%$ \\
\hline 2. & Medium extent of adoption & $26-35$ & 32 & $26.66 \%$ \\
\hline 3. & High extent of adoption & $35-44$ & 66 & $55.00 \%$ \\
\hline
\end{tabular}

Table.2 Item analysis of extent of adoption of hybrid rice seed production practices

\begin{tabular}{|c|c|c|c|c|c|c|c|c|c|c|}
\hline \multirow{3}{*}{ S. No } & \multirow{3}{*}{ Extent of adoption } & \multicolumn{6}{|c|}{ Response categories } & \multirow{3}{*}{$\begin{array}{l}\text { Total } \\
\text { score }\end{array}$} & \multirow{3}{*}{$\begin{array}{l}\text { Mean } \\
\text { score }\end{array}$} & \multirow{3}{*}{ Rank } \\
\hline & & \multicolumn{2}{|c|}{ Adopted } & \multicolumn{2}{|c|}{$\begin{array}{l}\text { Partially } \\
\text { adopted }\end{array}$} & \multicolumn{2}{|c|}{$\begin{array}{l}\text { Non } \\
\text { adopted }\end{array}$} & & & \\
\hline & & $\mathbf{f}$ & $\%$ & $\mathbf{f}$ & $\%$ & $\mathbf{f}$ & $\%$ & & & \\
\hline 1. & $\begin{array}{l}\text { Planting parental lines to come to } \\
\text { flowering } 21 \text { days either prior or } \\
\text { after the rice varieties grown } \\
\text { nearby fields start flowering }\end{array}$ & 100 & 83.33 & 15 & 12.50 & 5 & 4.16 & 335 & 2.79 & $\mathrm{I}$ \\
\hline 2. & $\begin{array}{l}\text { Following recommended seed rate } \\
\text { of } 12 \mathrm{~kg} / \mathrm{ac} \& 6 \mathrm{~kg} / \mathrm{ac} \text { for female } \\
\text { and male respectively. }\end{array}$ & 60 & 50.00 & 40 & 33.33 & 20 & 16.60 & 280 & 2.33 & VII \\
\hline 3. & $\begin{array}{l}\text { Applying recommended quantity } \\
\text { of FYM in last puddling }\end{array}$ & 45 & 37.50 & 50 & 41.66 & 25 & 20.83 & 260 & 2.16 & XI \\
\hline 4. & $\begin{array}{l}\text { Transplanting the seedlings at the } \\
\text { age of } 20-25 \text { days. }\end{array}$ & 90 & 75.00 & 25 & 20.83 & 5 & 4.16 & 325 & 2.70 & II \\
\hline 5. & $\begin{array}{l}\text { Following seed treatment in paddy } \\
\text { with Carbendazim. }\end{array}$ & 56 & 46.6 & 34 & 28.33 & 30 & 25.00 & 266 & 2.21 & $\mathrm{X}$ \\
\hline 6. & $\begin{array}{l}\text { Following chemical weed control } \\
\text { with Butachlor @ } 2.51 / \text { ha. }\end{array}$ & 87 & 72.50 & 18 & 15.00 & 15 & 12.50 & 312 & 2.60 & $\mathrm{~V}$ \\
\hline
\end{tabular}




\begin{tabular}{|c|c|c|c|c|c|c|c|c|c|c|}
\hline \multirow{3}{*}{ S. No } & \multirow{3}{*}{ Extent of adoption } & \multicolumn{6}{|c|}{ Response categories } & \multirow{3}{*}{$\begin{array}{l}\text { Total } \\
\text { score }\end{array}$} & \multirow{3}{*}{$\begin{array}{l}\text { Mean } \\
\text { score }\end{array}$} & \multirow{3}{*}{ Rank } \\
\hline & & \multicolumn{2}{|c|}{ Adopted } & \multicolumn{2}{|c|}{$\begin{array}{l}\text { Partially } \\
\text { adopted }\end{array}$} & \multicolumn{2}{|c|}{$\begin{array}{l}\text { Non } \\
\text { adopted }\end{array}$} & & & \\
\hline & & $\mathbf{f}$ & $\%$ & $\mathbf{f}$ & $\%$ & $\mathbf{f}$ & $\%$ & & & \\
\hline 7. & $\begin{array}{l}\text { Following rope pulling during } \\
\text { anthesis for supplementing the } \\
\text { pollination. }\end{array}$ & 58 & 48.33 & 34 & 28.33 & 30 & 25.00 & 272 & 2.26 & VIII \\
\hline 8. & $\begin{array}{l}\text { Spraying } \mathrm{GA}_{3} \text { before flowering } \\
\text { stage for promotion of panicle } \\
\text { exertion and growth of secondary } \\
\text { and tertiary tillers }\end{array}$ & 80 & 66.60 & 32 & 26.60 & 14 & 11.66 & 318 & 2.65 & IV \\
\hline 9. & $\begin{array}{l}\text { Rouging at tillering, flowering } \\
\text { and at maturity stage improves } \\
\text { quality of seed production in } \\
\text { hybrid rice }\end{array}$ & 88 & 73.30 & 20 & 16.66 & 18 & 15.00 & 322 & 2.68 & III \\
\hline 10. & $\begin{array}{lcc}\text { Staggered } & \text { sowing } \\
\text { synchronisation in flowering } & \text { for }\end{array}$ & 82 & 68.33 & 22 & 18.33 & 16 & 13.33 & 306 & 2.55 & VI \\
\hline 11 & $\begin{array}{l}\text { Following isolation distance of } \\
100 \mathrm{mts} \text {. }\end{array}$ & 100 & 83.33 & 15 & 12.50 & 5 & 4.16 & 335 & 2.79 & $\mathrm{I}$ \\
\hline 12 & $\begin{array}{l}\text { Clipping of flag leaf for wide } \\
\text { dispersal of pollen grains to get } \\
\text { higher seed yield }\end{array}$ & 80 & 66.60 & 32 & 26.60 & 14 & 11.66 & 318 & 2.65 & IV \\
\hline 13 & $\begin{array}{l}\text { Spray of } 2 \% \text { urea delays and } \\
\text { phosphoric fertilisers enhances the } \\
\text { flowering by } 2-3 \text { days }\end{array}$ & 82 & 68.33 & 22 & 18.33 & 16 & 13.33 & 306 & 2.55 & VI \\
\hline 14. & $\begin{array}{l}\text { The } A \text { and } R \text { lines are grown in } \\
\text { 10:2 row ratio for hybrid rice seed } \\
\text { production }\end{array}$ & 88 & 73.30 & 20 & 16.66 & 18 & 15.00 & 322 & 2.68 & III \\
\hline 15 & $\begin{array}{l}\text { Nursery beds should be top } \\
\text { dressed with nitrogen @ } 600-800 \\
\mathrm{~g} \text { per } 100 \mathrm{~m}^{2} \text { of area. }\end{array}$ & 49 & 40.83 & 51 & 42.50 & 20 & 16.60 & 269 & 2.24 & IX \\
\hline
\end{tabular}

It could be inferred from the table 2 that the high adoption of some of the hybrid rice seed production technologies by the respondents could be attributed to the continuous supervision and advisory system of private seed production companies to guide the farmers to strictly apply these techniques which are highly essential for effective seed production in rice crop like (high ranked practices)- planting the parental lines to come to flowering 21 days either prior or after the rice varieties grown nearby fields start flowering, practicing isolation distance of 100 $\mathrm{mts}$, transplanting the seedlings at the age of 20-25 days, rouging at tillering, flowering and at maturity stage, application of GA3 before flowering stage, clipping of flag leaf for wide spread of pollen grains, following chemical 
weed control with Butachlor @ 2.5 1/ha, staggered sowing for synchronisation in flowering, Spray of $2 \%$ urea delays and phosphoric fertilisers enhances the flowering by 2-3 days, recommended seed rate of 12 $\mathrm{kg} / \mathrm{ac}$ and $6 \mathrm{~kg} / \mathrm{ac}$ for female and male respectively, following rope pulling during anthesis for supplementing the pollination.

These practices are easy to adopt without trying to understand much of the science in it and also not much external inputs are required.

The least ranked practices are- nursery beds should be top dressed with nitrogen @ 600$800 \mathrm{~g}$ per $100 \mathrm{~m}^{2}$ of area (IX rank), following seed treatment in paddy with Carbendazim (X) and applying recommended quantity of FYM on last puddling.

The reason for their poor adoption may be due to lack of sufficient technical guidance on those above practices, apart from requiring costly inputs, due to dwindling livestock population the availability of FYM is coming down. The state agriculture university and state department of agriculture should organise need based skill oriented training programmes especially through KVKs and other institutes to hasten up the adoption of these practices.

Majority of the respondents had high extent of adoption followed by medium and low extent of adoption of hybrid rice seed production technologies. The least adopted items were practicing seed treatment in paddy with Carbendazim, applying recommended quantity of FYM on last puddling, maintaining improper seed rate.

The reason for their poor adoption may be due to lack of sufficient technical guidance on those above practices apart from requiring costly inputs, due to dwindling livestock population the availability of FYM is coming down. Training programmes and small group meetings may be organized to improve knowledge and skills of farmers on these technologies.

The state agriculture university and state department of agriculture should organize need based skill oriented training programmes especially through KVKs and other institutes to hasten up the adoption of these practices.

\section{References}

Hari Prasad, Senguttuvel, P., Revati, P., Kemparaju, K.B., Shobha, R. N and Viraktamath, B.C.V. 2011.Hybrid rice in India.DRR Technical Bulletin 48:4-5.

Naresh, R. K. Gupta Raj, K. Kumar Ashok, singh B. Prakash satya, Kumar Satish and Rathi, R.C. 2011. Direct seeding and reduced tillage options in the rice wheat system of the indo Gangetic plains. Indian journal of agricultural sciences, 7(1): 197-208.

Food and Agricultural Organization.2006. FAO production year Book, Rome. www.fao.org. 2013

\section{How to cite this article:}

Sadvi, P., M. Jagan Mohan Reddy and Sreenivasa Rao, I. 2017. Extent of Adoption of Hybrid Rice Seed Production Technologies by the Hybrid Rice Seed Growers. Int.J.Curr.Microbiol.App.Sci. 6(7): 2632-2636. doi: https://doi.org/10.20546/ijcmas.2017.607.371 